\title{
PERAN AUDITOR INTERNAL DAN MANAJEMEN RESIKO PADA PERUSAHAAN
}

\author{
Rudi Setiawan \\ 165100105 \\ Fakultas Komputer \\ rudisetiawan.student@umitra.ac.id
}

\begin{abstract}
Institute of Internal Auditors (IIA), menjelaskan kegiatan internal audit sebagai kegiatan independen yang mendukung pencapaian sasaran organisasi, dan aktivitas konsultasi yang dirancang untuk memberikan nilai tambah dan memperbaiki operasi organisasi. Aktivitas ini membantu organisasi untuk mencapai tujuannya dengan membawa pendekatan sistematik dan disiplin untuk mengevaluasi dan meningkatkan efektivitas manajemen risiko, pengendalian, dan proses governance. Tugas inti auditor internal berkaitan dengan manajemen risiko adalah untuk memberikan kepastian bahwa kegiatan manajemen risiko telah berjalan dengan efektif dalam memberikan jaminan yang wajar terhadap pencapaian sasaran organisasi.
\end{abstract}

Risk and Insurance Management Society (RIMS). Fungsi manajemen risiko bertanggung jawab untuk membentuk kerangka kerja dan proses manajemen risiko dalam menghadapi risiko-risiko signifikan yang dapat mempengaruhi pencapaian tujuan organisasi. Integrated risk management menerapkan kegiatan pencegahan dan pengurangan dampak negatif dari risiko. Seiring berjalannya waktu, manajemen risiko yang tadinya berperan untuk melindungi kegagalan organisasi, berubah menjadi komponen competitive advantage bagi organisasi. Selain menciptakan kerangka kerja dan proses manajemen risiko dalam menghadapi risiko, fungsi manajemen risiko juga meningkatkan kapabilitas organisasi dalam mengejar peluang

Fungsi ini juga meningkatkan kemampuan pengambilan keputusan strategis organisasi melalui penyediaan informasi yang relevan dan komprehensif. Dalam menciptakan manajemen risiko yang efektif bagi organisasi, fungsi manajemen risiko berkolaborasi dengan fungsi internal audit.

Kata Kunci : Audit dan Resiko. 


\section{A. PENDahuluan}

Pengertian Audit Internal, Audit Intern/Audit Internal yaitu Menurut Institute of internal Auditor Internal audit adalah suatu aktivitas independen,yang memberikan jaminan keyakinan serta konsultasi yang dirancang untuk memberikan jaminan keyakinan serta konsultasi yang dirangcang untuk memberikan suatu nilai tambah serta meningkatkan kegiatan operasi organisasi. Perkembangan profesi internal auditing, dewasa ini melaju sangat cepat seiring dengan perkembangan jaman pada era globalisasi. Adapun definisi atau pengertian internal auditing juga mengalami perubahan dari waktu ke waktu. Pengertian Internal Auditing adalah proses pemeriksaan internal atas pengendalian yang dilakukan manajemen apakah berjalan dengan baik serta efektif, hingga unit unit yang menjalankan sudah sesuai dengan prosedur prosedur yang telah ditetapkan. Pihak yang memeriksa adalah auditor internal, artinya yang memeriksa itu adalah "karyawan" perusahaan itu sendiri, untuk tujuan pihak manajemen, tujuan internal perusahaan, tidak untuk pihak eksternal. Internal audit bertujuan untuk membantu anggota entitas organisasi supaya bisa melaksanakan tanggung jawab dengan efektif.Internal Audit akan menganalisis, mengajukan beberapa saran dan penilaian. pemeriksaaan juga mencakup pengawasan efektif dgan biaya yg wajar. Audit Internal bertujuan untuk membantu manajemen dalam melaksanakan tanggungjawabnya dengan menganalisa, menilai dan memberiksaran serta komentar tentang aktivitas yang diperiksa. Internal audit berfungsi untuk alat bantu manajemen guna menilai tingkat efektif dan keefisienan pengendalian internal perusahaan, memberi saran ataupun rekomendasi serta memberikan nilai tambah untuk manajemen sebagai dasar pengambilan keputusan atau tindakan berikutnya. Pada dasarnya Manajemen Risiko adalah penerapan fungsi-fungsi manajemen dalam penanggulangan risiko, terutama risiko yang dihadapi oleh organisasi/perusahaan, keluarga dan masyarakat. Jadi Manajemen Risiko mencakup kegiatan merencanakan, 
mengorganisasikan, memimpin, mengkoordinir dan mengawasi program penanggulangan risiko. Tujuan Manajemen Risiko di perusahaan pada dasarnya untuk mengamankan perusahaan dari kemungkinan perusahaan terkena kerugian dan meminimalkan kerugian bila peril sudah terjadi. Pelaksanaan yang baik dari fungsi manajemen risiko dan fungsi audit internal dalam suatu struktur perusahaan masih menjadi perdebatan hingga saat ini. Terdapat beberapa pendapat yang mencoba untuk menyelesaikan masalah tersebut. Pendapat pertama menyatakan bahwa fungsi manajemen risiko dan fungsi audit internal dapat disatukan, tetapi dibutuhkan pengelolaan yang lebih hatihati terhadap situasi tersebut. Pendapat kedua menyatakan bahwa fungsi internal audit perlu menjaga independensinya untuk menilai kelayakan fungsi manajemen risiko. Tulisan ini dibuat bukan untuk membuktikan pendapat mana yang benar, melainkan untuk memberi landasan teori mengenai pendapat-pendapat tersebut dan memberikan contoh pelaksanaannya di beberapa perusahaan di Indonesia. Setiap perusahaan menghadapi risiko yang menjadi kendala bagi mereka dalam usaha mencapai tujuan. Penerapan manajemen risiko yang efektif pada perusahaan merupakan salah satu alat penting bagi manajemen untuk menciptakan tata kelola perusahaan yang baik atau Good Corporate Governance (GCG). Menurut Keputusan Ketua Badan Pengawas Pasar Modal dan Lembaga Keuangan Nomor: KEP- 480/BL/2009, pelaksanaan fungsi manajemen risiko dilakukan berdasarkan suatu strategi manajemen risiko.

\section{B. PEMBAHASAN / STUDI KASUS}

Audit Internal atau Internal Audit memiliki peranan penting dalam keberjalanan perusahaan. Pada era modern ini perkembangan Manajemen organisasi khususnya di perusahaan sangat memerlukan peran audit internal. Audit internal digunakan untuk mendukung keberjalanan manajemen perusahaan sebagai fungsi controlling yang menjamin perusahaan berjalan sesuai dengan perencanaan dan mengarah kepada tujuan. Biasanya audit internal dilakukan oleh unit yang berada di dalam perusahaan yang memang ditugaskan untuk melakukan audit terhadap perusahaan yang bersangkutan. Pelaksana dari audit internal adalah auditor internal. Pelaksana dari audit internal atau auditor internal biasanya ada pada perusahaan besar dimana perusahaan tersebut memiliki struktur 
organsasi yang kompleks dengan berbagai tugas dan fungsi masing-masing. Adapun tugas internal audit yang dilakukan auditor adalah melakukan audit internal perusahaan dengan menjamin sistem/manajemen yang ada di perusahaan supaya berjalan sesuai yang diinginkan. Selain itu dengan adanya audit internal dapat menghindari adanya resiko kesalahan, penyalahgunaan, dan kendala dengan mengembangkan efisiensi dan efektivitas perusahaan. Oleh karena itu perusahaan seharusnya menyusun SOP audit internal serta melakukan pengendalian internal audit di dalam perusahaan dnegan tujuan pengembangan perusahaan. Melihat pentingnya audit internal bagi perusahaan maka perlu adanya pembahasan mengenai audit internal secara tersendiri. Pada artikel ini akan dibahas secara terperinci mengenai pengertian audit internal, tujuan, fungsi, tuang lingkup, tanggung jawab dan aktivitas dalam audit internal. Arti internal audit adalah proses penilaian yang dilaksanakan secara berurutan dan bersifat obyektif yang dilaksanakan oleh auditor internal kepada aktivitas operasional dan kontrol yang berbeda di dalam organisasi. Audit internal dilaksanakan untuk menetapkan apakah : Informasi mengenai finansial dan operasional perusahaan sudah tepat dan dapat dipercaya. Kemungkinan hambatan yang akan dihadapi perusahaan telag diketahui dan diminimalisasi.Peraturan bagi eksternal perusahaan dan kebijakan di internal dapat diteirma dan dipatuhi. Aktivitas operasional sudah memuaskan. Penggunaan sumber daya perusahaan dipakai secara efektif dan efisien. Tujuan organisasi/perusahaan diraih secara efektif. Hal ini didiskusikan dengan pihak manajemen dan memberikan bantuan berupa saran kepada anggota untuk menjalankan tugas seefektif mungkin. Menurut ISO 31000: 2009 Risk Management - Principles and Guidelines, manajemen risiko adalah upaya organisasi yang terkoordinasi untuk mengarahkan dan mengendalikan risiko sehingga manajemen risiko merupakan arsitektur untuk mengelola risiko secara sistematis, yang terdiri dari prinsip, kerangka kerja, dan proses untuk mengelola risiko. Manajemen risiko juga dijelaskan dalam Peraturan Menteri Keuangan Nomor 142/PMK.010/2009 sebagai serangkaian prosedur dan metodologi yang digunakan untuk mengidentifikasi, mengukur, memantau, dan mengendalikan risiko yang timbul dari kegiatan usaha. Semakin berkembangnya perusahaan maka kegiatan dan masalah yang dihadapi perusahaan 
semakin kompleks. Oleh sebab itu, selain dari penerapan manajemen risiko yang baik, perusahaan perlu memiliki internal control atau pengendalian internal sebagai salah satu kebijakan yang dapat dijalankan oleh manajemen perusahaan dalam meningkatkan kinerja perusahaannya. Pengendalian internal mempunyai peranan yang sangat penting bagi suatu organisasi perusahaan. Pengendalian internal merupakan alat yang baik untuk membantu manajemen dalam menilai operasi perusahaan guna dapat mencapai tujuan usaha. Untuk menjaga agar sistem pengendalian internal dapat dilaksanakan, diperlukan adanya bagian yang berfungsi melaksanakan tugas pengawasan atau audit internal. Fungsi yang dimaksudkan merupakan upaya tindakan pencegahan, penemuan penyimpangan-penyimpangan (fraud) melalui pembinaan dan pemantauan pengendalian internal secara terus-menerus. Fungsi ini harus membuat suatu program yang sistematis dengan mengadakan observasi langsung, pemeriksaan dan penilaian atas pelaksanaan kebijakan pimpinan serta pengawasan sistem informasi akuntansi dan keuangan lainnya. Pelaku yang menjalankan fungsi ini disebut dengan internal auditor. Sesuai dengan pengertian dan fungsinya, maka internal auditor melaksanakan tugasnya sebagai berikut,Mengevaluasi secara terus-menerus apakah Sistem Pengendalian Intern (SPI) perusahaan telah memadai dan berjalan sesuai dengan ketentuan, Memverifikasi setiap transaksi apakah telah dilaksanakan sesuai dengan sistem dan prosedur, serta ketentuan perusahaan dan undang-undang yang berlaku, Menyampaikan informasi tentang kondisi (adanya penyimpangan atau transaksi yang berjalan tidak sesuai dengan prosedur dan ketentuan yang berlaku) yang diperoleh dari hasil audit, dan membuat saran-saran perbaikan kepada manajemen melalui laporan hasil audit. Berdasarkan tugas-tugas yang dilaksanakan tersebut, apabila dalam audit ditemukan adanya penyimpangan, maka auditor akan menginformasikan kepada manajemen tentang hal penyimpangan yang ditemukan, dan mengapa hal tersebut terjadi serta siapa yang melakukannya. Atas dasar temuan tersebut, auditor akan memberikan saran atau rekomendasi kepada manajemen.

\section{ID SECURITY QWTD4452377-ASP-5244107}

\section{KESIMPULAN}

Audit Internal atau Internal Audit memiliki peranan 
penting dalam keberjalanan perusahaan. Pada era modern ini perkembangan Manajemen organisasi khususnya di perusahaan sangat memerlukan peran audit internal. Audit internal digunakan untuk mendukung keberjalanan manajemen perusahaan sebagai fungsi controlling yang menjamin perusahaan berjalan sesuai dengan perencanaan dan mengarah kepada tujuan. Adapun tugas internal audit yang dilakukan auditor adalah melakukan audit internal perusahaan dengan menjamin sistem/manajemen yang ada di perusahaan supaya berjalan sesuai yang diinginkan. Selain itu dengan adanya audit internal dapat menghindari adanya resiko kesalahan, penyalahgunaan, dan kendala dengan mengembangkan efisiensi dan efektivitas perusahaan. Oleh karena itu perusahaan seharusnya menyusun SOP audit internal serta melakukan pengendalian internal audit di dalam perusahaan dengan tujuan pengembangan perusahaan. Manajemen risiko terdiri dari dua kata berbeda. Seperti yang kita tahu manajemen secara umum berarti mengorganisir. Sedangkan dalam KBBI kata risiko berarti : akibat yang kurang menyenangkan (merugikan, membahayakan) dari suatu perbuatan atau tindakan. Dalam bisnis sendiri, risiko berkaitan dengan hasil aktual yang tidak sesuai dengan hasil harapan. Menangani risiko dengan menghindar bisa sangat efektif bila keuntungan yang didapat tidak sebanding dengan risiko yang akan diterima. Tapi strategi ini juga tidak bisa digunakan sebagai cara utama karena kita mungkin melewatkan keuntungan besar dari risiko yang kita hadapi. Jadi kita harus tahu secara jelas bagaimana karakteristik dari risiko tersebut dan telah mengujinya dengan bebrapa cara lain. Cara yang kedua adalah dengan mengurangi risiko yang diterima. Cara ini bisa dibilang paling umum dan cocok pada rentang risiko yang luas. Kita tetap bisa beraktivitas seperti biasa namun dengan bahaya yang berkurang. Namun kekurangannya adalah saat kontrol kita tidak efektif risiko yang kita takutkan bisa terjadi.

\section{E. DISKUSI}

Saya telah berdiskusi dengan kawan saya yaitu Muklis, menurut dia Internal audit adalah kegiatan yang independen dan objectif beserta konsultasi yang disusun untk meningkatkan nilai dan operasional organisais/perusahaan. Internal audit dapat mendukung organisasi/perusahaan dalam pencapaian tujuannya dengan cara pendekatan yang terstruktur dan disiplin. Pendekatan internal audit 
tersebut dilakukan dengan cara evaluasi dan meningkatkan keefektifan manajemen resiko, controlling dan proses tata kelola. tujuan internal audit adalah membantu manajemen perusahaan menjalankan tugas melalui analisa, penilaian, dan pemberian saran dan masukan mengenai kegiatan/program (yang masuk dalam pemeriksaan). Manajemen resiko adalah suatu sistem pengawasan risiko dan perlindungan harta benda, hak milik dan keuntungan badan usaha atau perorangan atas kemungkinan timbulnya kerugian karena adanya suatu risiko. Proses pengelolaan risiko yang mencakup identifikasi, evaluasi dan pengendalian risiko yang dapat mengancam kelangsungan usaha atau aktivitas perusahaan Suatu pendekatan terstruktur/ metodologi dalam mengelola ketidakpastian yang berkaitan dengan ancaman; suatu rangkaian aktivitas manusia termasuk: Penilaian risiko, pengembangan strategi untuk mengelolanya dan mitigasi risiko dengan menggunakan pemberdayaan /pengelolaan sumberdaya

\section{F. REFERENCE}

[1] O. M. Febriani and A. S. Putra, 
"Sistem Informasi Monitoring Inventori Barang Pada Balai Riset Standardisasi Industri Bandar Lampung," J. Inform., vol. 13, no. 1, pp. 90-98, 2014.

[2] A. S. Putra, "Paperplain: Execution Fundamental Create Application With Borland Delphi 7.0 University Of Mitra Indonesia," 2018.

[3] A. S. Putra, "2018 Artikel Struktur Data, Audit Dan Jaringan Komputer," 2018.

[4] A. S. Putra, "ALIAS MANAGER USED IN DATABASE DESKTOP STUDI CASE DB DEMOS."

[5] A. S. Putra, "COMPREHENSIVE SET OF PROFESSIONAL FOR DISTRIBUTE COMPUTING."

[6] A. S. Putra, "DATA ORIENTED RECOGNITION IN BORLAND DELPHI 7.0."

[7] A. S. Putra, "EMBARCADERO DELPHI XE 2 IN GPUPOWERED FIREMONKEY APPLICATION."

[8] A. S. Putra, "HAK ATAS KEKAYAAN INTELEKTUAL DALAM DUNIA TEKNOLOGY BERBASIS REVOLUSI INDUSTRI 4.0."

[9] A. S. Putra, "IMPLEMENTASI PERATURAN PERUNDANGAN UU. NO 31 TAHUN 2000 TENTANG DESAIN INDUSTRI BERBASIS INFORMATION TECHNOLOGY."

\begin{tabular}{|c|}
\hline $\begin{array}{l}\text { A. } \\
\text { "IMPLEMENTATION }\end{array}$ \\
\hline ARADOX DBASE." \\
\hline
\end{tabular}

[11] A. A. S. Putra, "IMPLEMENTATION OF
TRADE SECRET CASE STUDY SAMSUNG MOBILE PHONE."

A. S. Putra, "IMPLEMENTATION

PATENT FOR APPLICATION WEB BASED CASE STUDI WWW. PUBLIKLAMPUNG. COM."

[13] A. S. Putra, "IMPLEMENTATION SYSTEM FIRST TO INVENT IN DIGITALLY INDUSTRY."

[14] A. S. Putra, "MANUAL REPORT \& INTEGRATED DEVELOPMENT

ENVIRONMENT BORLAND DELPHI 7.0."

[15] A. S. Putra, "PATENT AS RELEVAN SUPPORT RESEARCH.”

[16] A. S. Putra, "PATENT FOR RESEARCH STUDY CASE OF APPLE. Inc."

[17] A. S. Putra, "PATENT PROTECTION FOR APPLICATION INVENT."

[18] A. S. Putra, "QUICK REPORT IN PROGRAMMING."

[19] A. S. Putra, "REVIEW CIRCUIT LAYOUT COMPONENT

REQUIREMENT ON ASUS NOTEBOOK."

[20] A. S. Putra, "REVIEW TRADEMARK PATENT FOR INDUSTRIAL TECHNOLOGY BASED 4.0."

[21] A. S. Putra, "TOOLBAR COMPONENT PALLETTE IN OBJECT ORIENTED PROGRAMMING."

[22] A. S. Putra, "WORKING DIRECTORY SET FOR 
PARADOX 7."

[23] A. S. Putra, "ZQUERY CONNECTION

IMPLEMENTED

PROGRAMMING STUDI

CASE PT. BANK BCA Tbk."

[24] A. S. Putra, D. R. Aryanti, and I. Hartati, "Metode SAW (Simple Additive Weighting) sebagai Sistem Pendukung Keputusan Guru Berprestasi (Studi Kasus: SMK Global Surya)," in Prosiding Seminar Nasional Darmajaya, 2018, vol. 1, no. 1, pp. 85-97.

[25] A. S. Putra and O. M. Febriani, "Knowledge Management Online Application in PDAM Lampung Province," in Prosiding International conference on Information Technology and Business (ICITB), 2018, pp. 181-187.

[26] A. S. Putra, O. M. Febriani, and B. Bachry, "Implementasi Genetic Fuzzy System Untuk Mengidentifikasi Hasil Curian Kendaraan Bermotor Di Polda Lampung," SIMADA (Jurnal Sist. Inf. dan Manaj. Basis Data), vol. 1, no. 1, pp. 21-30, 2018.

[27] A. S. Putra, H. Sukri, and K. Zuhri, "Sistem Monitoring Realtime Jaringan Irigasi Desa (JIDES) Dengan Konsep Jaringan Sensor Nirkabel," IJEIS (Indonesian J. Electron. Instrum. Syst., vol. 8, no. 2, pp. 221-232.

[28] D. P. Sari, O. M. Febriani, and A. S. Putra, "Perancangan Sistem Informasi SDM Berprestasi pada SD Global Surya," in Prosiding Seminar
Nasional Darmajaya, 2018, vol. 1, no. 1, pp. 289-294. 